\title{
IMPLEMENTASI JARINGAN SYARAF TIRUAN DALAM MEMPREDIKSI FREKUENSI RESONANSI ATENA MIKROSTRIP
}

\author{
Khairi Budayawan $^{1)}$, Yuhandri' ${ }^{2}$, Gunadi Widi Nurcahyo ${ }^{3)}$ \\ ${ }^{1}$ Prodi Pendidikan Teknik Elektronika, Universitas Negeri Padang \\ ${ }^{23}$ Fakultas Ilmu Komputer, Universitas Putra Indonesia YPTK \\ e-mail : ${ }^{1}$ khairi@,ft.unp.ac.id, ${ }^{2}$ yuhandri yunus@gmail.com, ${ }^{3}$ gunadiwidi@yahoo.co.id
}

\begin{abstract}
The resonant frequency of an antenna is determined by the dimensional parameters and permittivity of the antenna substrate. Generally, to get the resonant frequency, a complex mathematical formula is needed to solve. For this reason, an intelligent method is offered to determine the resonant frequency more easily. In this study, an artificial neural network method with Backpropagation algorithm is used to overcome the problem. The data used were consisting of 80 training data and 15 testing data. The results have shown that the artificial neural network learning method with the backpropagation algorithm was successfully utilized to calculate the resonant frequency of microstrip antennas, where the precision of the resonant frequency obtained of $93.33 \%$ at an error of $\leq 1 \%$, and $100 \%$ at an error of $\leq 2 \%$.
\end{abstract}

Keywords: Artificial Neural Network, Backpropagation, Microstrip Antenna, Resonant Frequency

\section{INTISARI}

Frekuensi resonansi antena sangat ditentukan oleh parameter dimensi dan permitivitas substrat antena. Umumnya untuk mendapatkan frekuensi resonansi tersebut dibutuhkan rumus matematis yang rumit. Untuk itu dibutuhkan suatu metode agar dapat menentukan frekuensi resonansi yang lebih mudah. Penelitian ini digunakan metode JST dengan algoritma Backpropagation untuk mengatasi masalah tersebut. Data yang digunakan dalam penelitian sebanyak 80 data training dan 15 data uji. Hasil penelitian memperlihatkan bahwa metode pembelajaran Jaringan Syaraf Tiruan menggunakan algoritma Backpropagation berhasil dengan baik digunakan untuk menghitung frekuensi resonansi antena mikrostrip, dimana presisi dari frekuensi resonansi yang diperoleh adalah sebesar $93.33 \%$ pada error $\leq$ $1 \%$, dan $100 \%$ pada error $\leq 2 \%$.

Kata kunci : jaringan syaraf tiruan, backpropagation, antena mikrostrip, frekuensi resonansi

\section{PENDAHULUAN}

Dalam sistem komunikasi wireless, antena merupakan salah satu komponen yang sangat penting. Rancangan antena yang baik dapat membuat sistem bekerja dengan mudah dan dapat meningkatkan performa sistem secara keseluruhan. Selama 50 tahun terakhir, teknologi antena telah menjadi mitra revolusi komunikasi yang tak tergantikan. Banyak kemajuan yang telah terjadi selama periode ini dan umum digunakan saat ini, dan merupakan efek dari semakin banyaknya tuntutan akan performa sistem yang lebih besar. Permintaan akan aplikasi wireless yang terus bertambah mengakibatkan permintaan akan desain antena yang terintegrasi dan memiliki gain yang besar semakin meningkat [1].

Dari berbagai macam type antena, salah satu yang populer digunakan adalah antena mikrostrip. Antena mikrostrip memiliki fitur menarik yaitu profil rendah, ringan, narrow bandwidth, kompatibel terhadap permukaan planar dan nonplanar, mudah dipabrikasi dan integrasi dengan rangkaian microwave [2]. Antena mikrostrip telah populer digunakan dalam komunikasi bergerak [34] yang sedang trend saat ini.

Setiap antena dibuat sesuai dengan kebutuhan frekuensi yang diminta. Penghitungan frekuensi resonansi antena sulit dilakukan secara 
matematis, karena banyak parameter-parameter yang mempengaruhi dalam perhitungan, di antaranya jenis subtrat, ketebalan subtrat, dimensi antena, dan bahkan kondisi lingkungan juga mempengaruhi. Tabel 1 merupakan perbandingan hasil perhitungan antena [5] dengan hasil simulasi menggunakan aplikasi CST Microwave Studio memperlihatkan perbedaan yang cukup signifikan yaitu rata-rata persentase error mencapai $3.33 \%$. Hasil tersebut menunjukkan bahwa perhitungan frekuensi antena dengan menggunakan persamaan matematis tersebut tidak dapat memprediksi frekuensi resonansi antena secara akurat.

Tabel 1 Perbandingan Hasil Perhitungan dan Hasil Simulasi Antena

\begin{tabular}{lllrrrrrl}
\hline $\begin{array}{c}\text { No } \\
.\end{array}$ & $\varepsilon \cdot$ & $h$ & $L$ & $W$ & $X_{0}$ & $\begin{array}{c}f_{r} \\
\text { Hitung }\end{array}$ & $f_{r}$ CST & error \% \\
\hline 1 & 2 & 1 & 105.57 & 106.07 & 19.28 & 1.000 & 0.990 & 1.00 \\
2 & 2 & 1 & 52.51 & 53.03 & 9.59 & 2.000 & 1.962 & 1.90 \\
3 & 2 & 1 & 34.80 & 35.36 & 6.36 & 3.000 & 2.922 & 2.60 \\
4 & 2 & 1 & 25.94 & 26.52 & 4.74 & 4.000 & 3.882 & 2.95 \\
5 & 2 & 1 & 20.62 & 21.21 & 3.77 & 5.000 & 4.818 & 3.64 \\
6 & 3 & 2 & 86.09 & 86.60 & 14.05 & 1.000 & 0.984 & 1.60 \\
7 & 3 & 2 & 42.65 & 43.30 & 6.96 & 2.000 & 1.944 & 2.80 \\
8 & 3 & 2 & 28.11 & 28.87 & 4.58 & 3.000 & 2.898 & 3.40 \\
9 & 3 & 2 & 20.81 & 21.65 & 3.39 & 4.000 & 3.846 & 3.85 \\
10 & 3 & 2 & 16.41 & 17.32 & 2.68 & 5.000 & 4.788 & 4.24 \\
11 & 5 & 3 & 66.75 & 67.08 & 9.48 & 1.000 & 0.978 & 2.20 \\
12 & 5 & 3 & 32.87 & 33.54 & 4.67 & 2.000 & 1.920 & 4.00 \\
13 & 5 & 3 & 21.47 & 22.36 & 3.05 & 3.000 & 2.856 & 4.80 \\
14 & 5 & 3 & 15.72 & 16.77 & 2.23 & 4.000 & 3.792 & 5.20 \\
15 & 5 & 3 & 12.26 & 13.42 & 1.74 & 5.000 & 4.710 & 5.80 \\
\hline Rata-rata persentase error \% & & & & 3.33 \\
\hline
\end{tabular}

Banyak metode yang dapat digunakan dalam menghitung frekuensi resonansi antena mikrostrip, seperti metode Transmission Line (TLM), Cavity Model, dan Method of Moment (MoM). Namun, untuk memperoleh hasil perhitungan yang mendekati dengan metode ini sangat sulit dilakukan dan memakan waktu. Beberapa metode atau teknik yang berbeda seperti Logika Fuzzy, Algoritma Genetik, dan Jaringan Syaraf Tiruan (JST) telah digunakan untuk untuk memperkirakan frekuensi resonansi dan bandwidth antena mikrostrip [6-7]. Berdasarkan hal tersebut maka masalah yang ada dapat dirumuskan yaitu bagaimana menggunakan metode Jaringan Syaraf Tiruan dengan algoritma backpropagation dalam memprediksi frekuensi resonansi antena mikrostrip.

Tujuan dari penelitian adalah menggunakan model Jaringan Syaraf Tiruan dengan algoritma backpropagation dalam memprediksi frekuensi resonansi Antena Mikrostrip. Proses pembelajaran untuk Jaringan Syaraf Tiruan menggunakan sebanyak 80 dan 15 data sebagai data pelatihan dan pengujian. Penelitian ini diharapkan dapat memudahkan dalam memprediksi frekuensi resonansi antena mikrostrip berdasarkan parameter dimensi antena dan permitivitas substrat.

\section{PENDEKATAN PEMECAHAN MASALAH}

JST adalah suatu model yang terinspirasi dari kerja jaringan syaraf biologis khususnya otak yang digunakan untuk memprediksi atau pendekatan fungsi yang bergantung pada sejumlah besar input dan pada umumnya tidak diketahui [8]. Sistem syaraf memiliki jutaan sel-sel syaraf di mana antara satu sama lain saling terhubung dan tiap-tiap syaraf tersebut melakukan tugas tertentu. Karena interkoneksi antara sel-sel itu rumit, hasil dari multi tugas sederhana ini adalah pelaksanaan tugas yang lebih kompleks dan lebih besar [9]. Mengadopsi cara kerja jaringan syaraf biologi, JST terdiri atas sejumlah besar neuron interkoneksi, di mana dari hal tersebut JST dapat meniru bagaimana sistem syaraf dalam memproses informasi pada manusia.

JST merupakan penggenerali-sasian model matematika yang berdasarkan jaringan syaraf secara biologi [10] dengan anggapan bahwa:

1) Proses informasi berada pada neuron-neuron

2) Sinyal dikirimkan antar neuron-neuron dengan menggunakan penghubung.

3) Penghubung antara neuron ini mempunyai nilai bobot yang dapat berfungsi untuk memperkuat atau memperlemah sinyal

4) Untuk menghasilkan output, pada setiap neuron memakai fungsi aktivasi yang diberikan pada setiap jumlah input yang diperoleh. Nilai output dan batas ambang nilai kemudian dibandingkan.

Terdapat 3 hal yang sangat menentukan pada JST yaitu: 1) pola hubungan antara neuron yang disebut arsitektur jaringan; 2) metode untuk penentuan bobot penghubung, biasa disebut dengan metode training (pelatihan) / learning (pembelajaran) / algoritma; dan 3) fungsi aktivasi. Contoh digambarkan pada Gambar 1 neuron $Y$ dengan input $x_{1}, x_{2}$ dan $x_{3}$. 


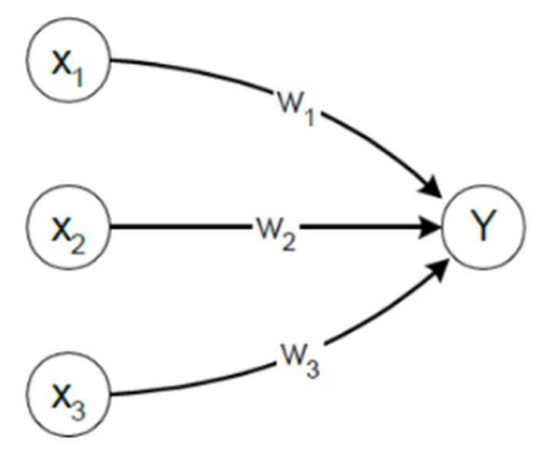

\section{Gambar 1. Pembobotan pada JST}

\section{Backpropagation}

Salah satu algoritma biasa dipakai dalam membantu menyelesaikan masalah yang komplek adalah Backpropagation. Ini dapat terjadi karena jaringan yang memakai algoritma tersebut dilatih menggunakan metode pembelajaran terpandu/terbimbing. Pada jaringan akan diberikan sepasang pola yang meliputi pola input dan pola yang diharapkan. Saat pola diberikan, dilakukan perubahan pada bobot dengan tujuan untuk memperkecil beda pola output dengan pola yang diharapkan. Latihan diberikan secara berulang hingga didapatkan pola output yang diharapkan.

\section{Backpropagation}

Backpropagation mempunyai beberapa unit yang berada pada satu atau lebih hidden layer. Arsitektur Backpropagation dengan sejumlah $n$ input dan hidden layer yang terdiri atas sejumlah $p$ unit, serta sejumlah $m$ unit output dijelaskan pada Gambar 2. $V_{j i}$ adalah nilai bobot garis dari unit input $X_{i}$ ke unit hidden layer $Z_{j}\left(V_{j 0}\right.$ adalah nilai bobot garis yang berfungsi menghubungkan bias pada unit input ke unit hidden layer $Z_{j}$ ). $W_{k j}$ adalah nilai bobot dari unit hidden layer $Z_{j}$ menuju unit output $Y_{k}\left(\mathrm{~W}_{k 0}\right.$ adalah nilai bobot bias hidden layer ke unit output $Z_{k}$ ).

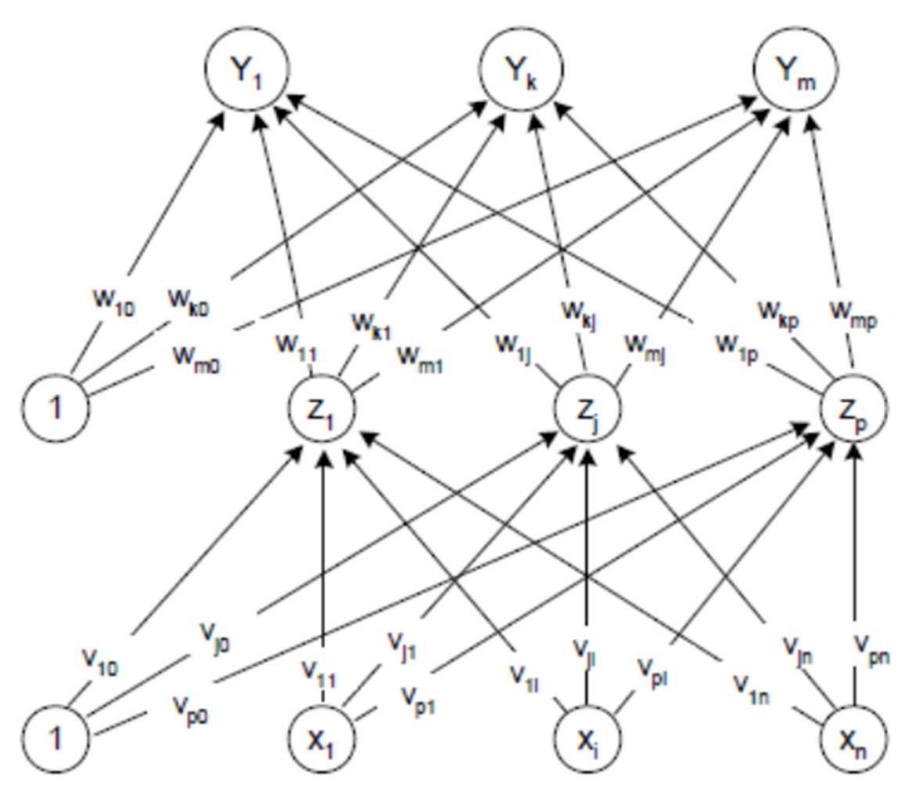

Gambar 2. Arsitektur Backpopagation

\section{Algoritma Backpropagation}

Pelatihan pada Backpropagation memiliki tiga fase yaitu: 1) fase propagasi maju; 2) fase propagasi mundur; dan 3) fase perubahan bobot. Ketiga fase tersebut dilakukan secara berulangulang hingga kondisi penghentian terpenuhi. Kondisi penghentian biasa dipakai adalah jumlah iterasi atau kesalahan. Iterasi akan dihentikan jika apabila jumlah iterasi yang dilakukan sudah melampaui jumlah maksimum iterasi yang ditetapkan, atau jika kesalahan yang terjadi sudah lebih rendah dari batas toleransi yang dibolehkan. Tahapan lebih detail untuk proses pelatihan dan proses pengujian diuraikan dalam algoritma. 


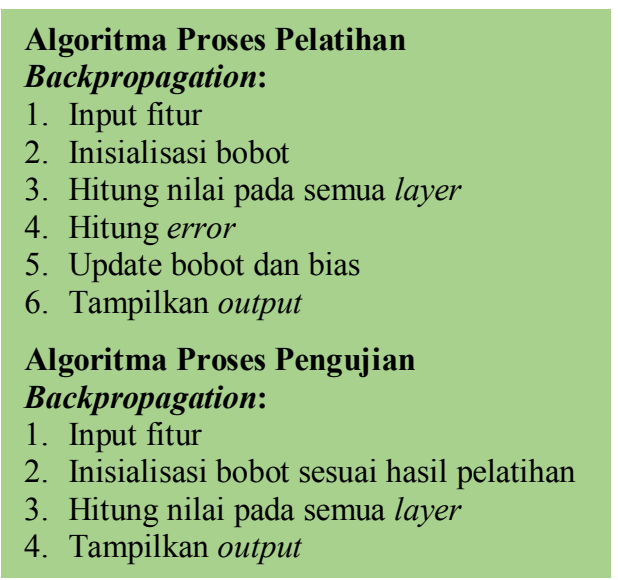

Berdasarkan penjelasan tentang algoritma Backpropagation dan kemudian diterjemahkan ke dalam bentuk flowchart yang kemudian implementasi dan pengujian menggunakan bahasa pemrograman Matlab. Flowchart algoritma pelatihan dan pengujian seperti terlihat pada Gambar 3 dan Gambar 4.

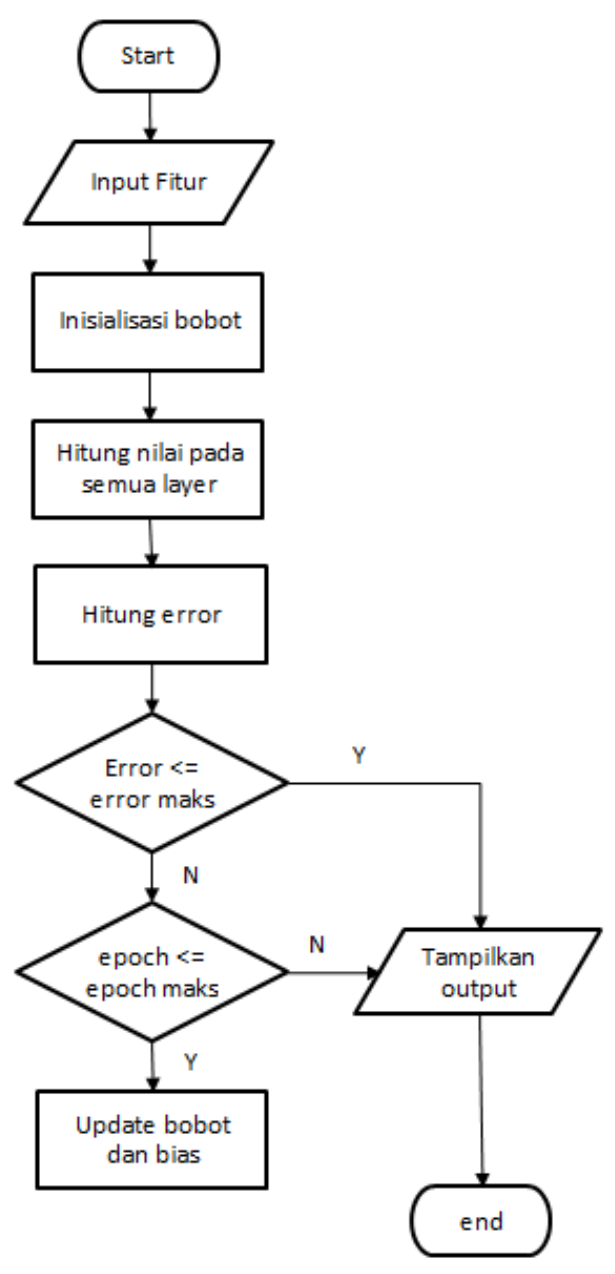

Gambar 3. Flowchart Pelatihan

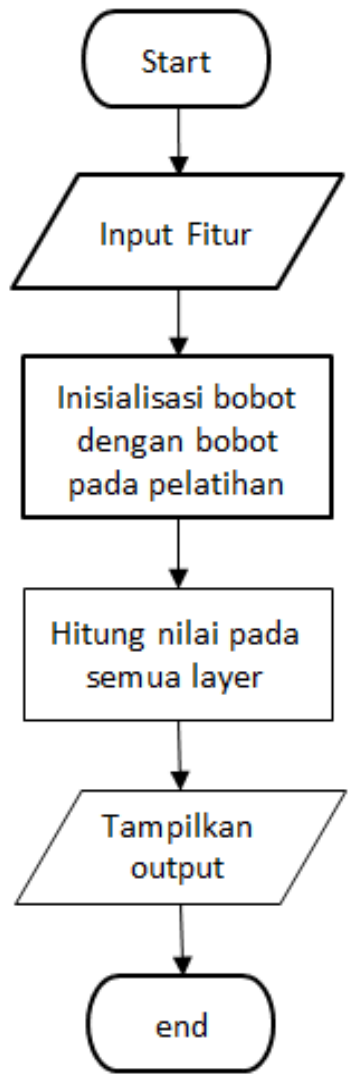

Gambar 4. Flowchart Pengujian

Algoritma pelatihan jaringan untuk yang memiliki satu hidden layer menggunakan fungsi aktivasi sigmoid biner dapat diuraikan atas [11]:

a) Tahap 0 : Dilakukan inisialisasi semua nilai bobot berdasarkan bilangan acak kecil

b) Tahap 1 : Bila belum didapatkan kondisi penghentian, laksanakan tahap 2 hingga 9

c) Tahap 2 : bagi setiap pasangan data pelatihan, laksanakan tahap 3 hingga 8

Fase I : Propagasi maju

d) Tahap 3 : setiap unit input menerima sinyal kemudian meneruskan ke unit hidden yang ada diatasnya

e) Tahap 4 : Hitung nilai semua output pada unit hidden $z_{j}(j=1,2, \ldots, \mathrm{p})$

$$
\begin{aligned}
& z_{-} \text {net }_{j}=v_{j 0}+\sum_{i=1}^{n} x_{i} v_{j i} \\
& z_{j}=f\left(z_{-} \text {net }_{j}\right)=\frac{1}{1+e^{-z_{-} \text {net }_{j}}}
\end{aligned}
$$

f) Tahap 5 : Hitung nilai semua keluaran jaringan pada unit $y_{k}(k=1,2, \ldots, m)$ 


$$
\begin{aligned}
& y_{-} n e t_{k}=w_{k 0}+\sum_{j=1}^{n} z_{i} w_{k j} \\
& y_{k}=f\left(k_{-} n e t_{k}\right)=\frac{1}{1+e^{-y_{-} n e t_{k}}}
\end{aligned}
$$

Fase II : Propagasi mundur

g) Tahap 6 : Lakukan perhitungan faktor $\delta$ unit output berdasarkan atas kesalahan pada setiap unit output $y_{k}(k=1,2, \ldots, m)$

$$
\begin{aligned}
& \delta_{k}=\left(t_{k}-y_{k}\right) f^{\prime}\left(y_{-} \text {net }_{k}\right)=\left(t_{k}-\right. \\
& \left.y_{k}\right) y_{k}\left(1-y_{k}\right)
\end{aligned}
$$

$\delta$ merupakan unit kesalahan dan digunakan untuk perubahan nilai bobot layer pada tingkat dibawahnya (tahap 7).

Hitung suku perubahan nilai bobot $w_{k j}$ (nanti digunakan untuk merubah nilai bobot $w_{k j}$ ) dengan laju percepatan $\alpha$.

$\Delta w_{k j}=\alpha \delta_{k} z_{j}$

$k=1,2, \ldots, m ; j=0,1, \ldots ., p$

h) Tahap 7 : Hitung faktor $\delta$ unit hidden berdasarkan kesalahan pada setiap unit hidden

$z_{j}(j=1,2, \ldots, p)$

$\delta \_n e t_{j}=\sum_{k=1}^{m} \delta_{k} w_{k j}$

Faktor $\delta$ unit hidden:

$$
\begin{aligned}
& \delta_{j}=\delta_{-} \text {net }_{j} f^{\prime}\left(z_{-} n e t t_{j}\right)= \\
& \delta_{-} \text {net }_{j} z_{j}\left(1-z_{j}\right)
\end{aligned}
$$

Hitung suku perubahan nilai bobot $v_{j i}$ (nanti dipakai dalam merubah nilai bobot $v_{j i}$ )

$$
\begin{aligned}
& \Delta v_{j i}=\alpha \delta_{j} x_{i} \\
& j=1,2, \ldots, p ; i=0,1, \ldots, n
\end{aligned}
$$

Fase III : Perubahan Bobot

i) Tahap 8 : Hitung semua nilai perubahan bobot Perubahan nilai bobot garis yang menuju ke unit output:

$$
\begin{aligned}
& w_{k j}(\text { baru })=w_{k j}(\text { lama })+ \\
& \Delta w_{k j} \quad(k=1,2, \ldots, m ; j=0,1, \ldots, p
\end{aligned}
$$

Perubahan nilai bobot garis yang menuju ke unit hidden :

$$
\begin{aligned}
& v_{j i}(\text { baru })=v_{j i}(\text { lama })+\Delta v_{j i} \quad(j= \\
& 1,2, \ldots, p ; i=0,1, \ldots, n
\end{aligned}
$$

Setelah pelatihan selesai dilaksanakan, jaringan dapat digunakan untuk melakukan pengenalan pola. Pada tahap ini hanya propagasi maju (tahap 4 serta 5) yang digunakan dalam menentukan output jaringan. Apabila sigmoid biner tidak digunakan sebagai fungsi aktivasi, maka tahap 4 dan 5 harus disesuaikan. Demikian pula untuk turunannya di tahap 6 dan 7

\section{Proses Pelatihan}

Arsitektur jaringan merupakan gambaran umum hubungan antar layer yang digunakan dalam proses pelatihan. Arsitektur Jaringan Syaraf Tiruan dengan algoritma backpropagation dalam prediksi frekuensi resonansi antena mikrostrip memiliki 5 buah masukan $\left(\varepsilon_{r}, h, L, W, x_{0}\right)$ dengan 1 bias, 1 buah hidden layer dengan 1 bias, serta 1 buah target pada output layer $\left(f_{r}\right)$, seperti terlihat pada Gambar 5 .

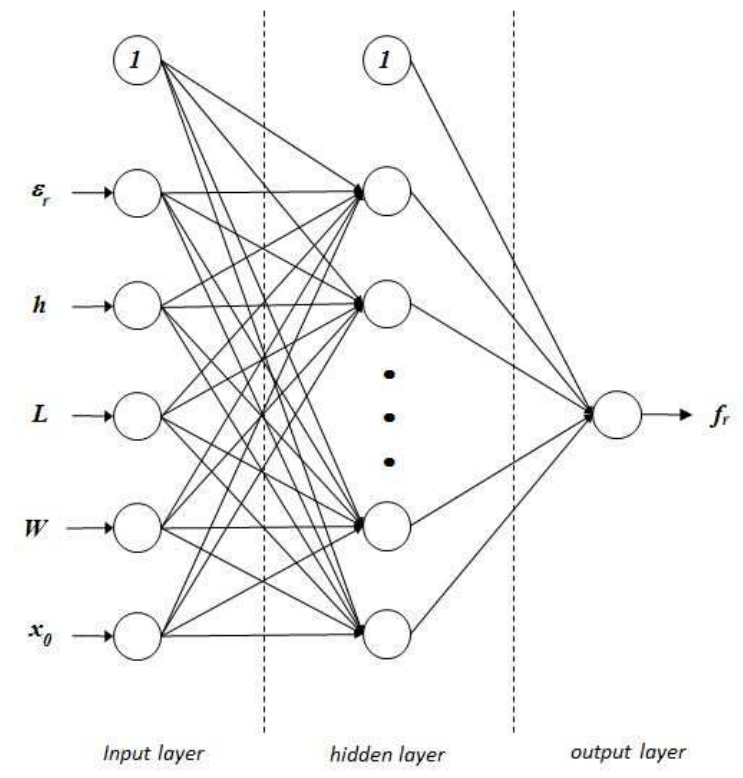

Gambar 5. Arsitektur Jaringan Syaraf Tiruan yang diusulkan

Berdasarkan arsitektur tersebut dapat ditentukan variabel pada input layer dan output 
layer, dimana $\varepsilon_{r}, h, L, W, x_{0}$ masing-masing diwakili oleh $X 1, X 2, X 3, X 4$, dan $X 5$ untuk input layer, dan $f_{r}$ diwakili dengan $Y$ pada output layer.

Sebelum memulai proses pelatihan, data yang digunakan harus dipastikan apakah sudah sesuai dengan fungsi aktivasi yang digunakan. Pada penelitian ini, fungi aktivasi yang digunakan adalah fungsi aktivasi sigmoid biner. Karena fungsi aktivasi sigmoid biner memiliki range $[0,1]$, maka data ditransformasikan terlebih dahulu ke interval $[0,1]$ dengan menggunakan persamaan:

$x^{\prime}=\frac{0.8(x-a)}{b-a}+0.1$

di mana $a$ merupakan nilai data minimum, dan $b$ adalah nilai data maksimum.

\section{Metode}

Penelitian dimulai dari mengidentifikasi masalah, menentukan tujuan, studi literatur, kemudian dilanjutkan dengan pengumpulan data yang akan digunakan untuk pelatihan pada Jaringan Syaraf Tiruan, merancang arsitektur Jaringan Syaraf Tiruan, implementasi algoritma backpropagation dan dilanjutkan pengujian hasil. Urutan tahapan kerangka kerja penelitian digambarkan pada Gambar 5.

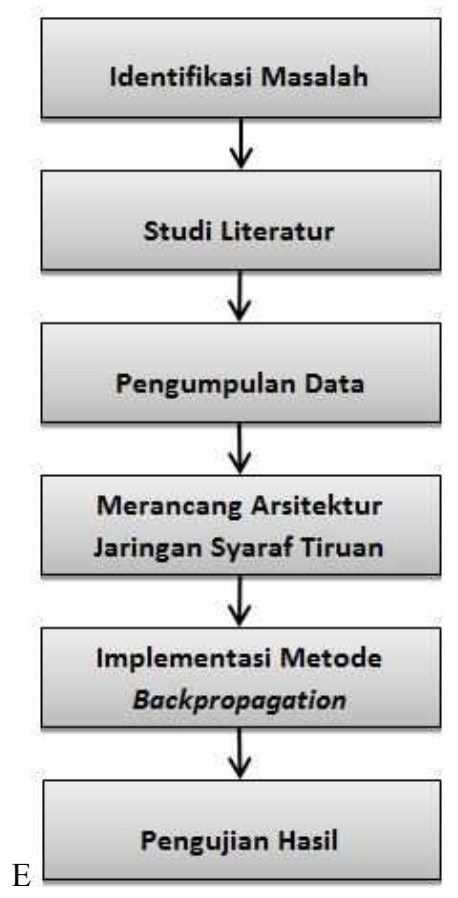

Gambar 5. Flowchart Pengujian
Berdasarkan kerangka kerja penelitian, maka dapat diuraikan sebagai berikut:

1. Identifikasi Masalah

Pada tahap inidilakukan proses penentuan masalah dan mendefenisikan batasan masalah yang akan diteliti, sehigga tujuan penelitian dapat tercapai dengan baik.

2. Studi Literatur

Pada tahap ini pengumpulan referensi dilakukan dan diambil dari penelitian terdahulu yang terkait dengan penelitian yang menggunakan Jaringan Syarat Tiruan untuk memprediksi suatu masalah.

3. Pengumpulan Data

Data dikumpulkan dari hasil simulasi menggunakan program aplikasi CST Microwave Studio, merupakan program aplikasi yang digunakan untuk simulasi elektromagnetik 3D untuk komponen frekuensi tinggi. Data yang diperoleh digunakan sebagai data untuk pelatihan Jaringan Syaraf Tiruan.

4. Merancang Arsitektur Jaringan Syaraf Tiruan Rancangan arsitektur yang tepat akan menentukan tingkat keberhasilan target yang akan dicapai, karena tidak semua permasalahan dapat dipecahkan dengan menggunakan arsitektur yang sama. Pada penelitian ini, karena permasalahan yang akan dipecahkan cukup sulit, maka arsitektur yang dipilih adalah jaringan dengan banyak lapisan (multilayer net), dengan 5 buah input masing-masing untuk parameter permitivitas $\varepsilon_{r}$, ketebalan substrat $h$, panjang patch $L$, lebar patch $W$, dan posisi feeding point $x$, dan 1 buah output untuk parameter Frekuensi Resonansi $f_{r}$.

5. Implementasi Metode Back propagation

Pada tahap ini Jaringan Syarat Tiruan dilatih/training dengan menggunakan data yang telah dikumpulkan sehingga siap untuk digunakan dalam memprediksi output yang diinginkan sesuai dengan input yang diberikan.

\section{HASIL DAN PEMBAHASAN}

Parameter-parameter yang diperlukan dalam membangun Jaringan Syaraf Tiruan ini meliputi learning rate, jumlah neuron pada bagian hidden layer, dan goal. Parameter epoch dan nilai learning rate ditentukan dengan melihat nilai means square error (MSE) saat pelatihan, dimana semakin kecil nilai MSE maka semakin bagus kinerja Jaringan Syaraf Tiruan. 
Nilai awal parameter arsitektur jaringan ditetapkan memiliki 5 input, 1 hidden layer dengan 5 neuron dan 1 output seperti terlihat pada Gambar 6. Fungsi aktivasi yang dipilih adalah fungsi aktivasi logsig pada lapisan input, fungsi aktivasi purelin untuk lapisan output, serta traingdx sebagai fungsi pelatihan jaringan. Inisialisasi nilai bobot dan bias dilakukan secara acak dengan range -1 hingga +1 .

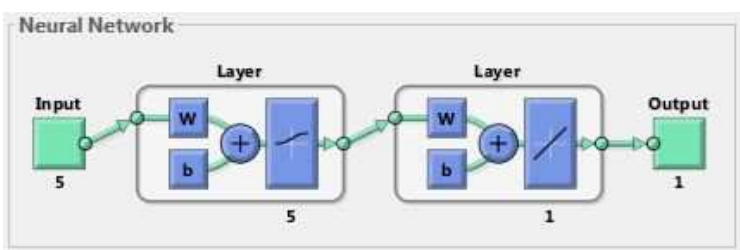

\section{Gambar 6. Arsitektur Jaringan Syaraf Tiruan algoritma Backpropagation.}

Setelah dilakukan beberapa kali pelatihan pada jaringan untuk mencari parameter-parameter pelatihan yang paling cocok [12], maka didapatkan hasil konfigurasi parameter untuk sistem Jaringan Syaraf Tiruan seperti terlihat pada Tabel 2.

Tabel 2 Konfigurasi Parameter Pelatihan Jaringan

\begin{tabular}{lll}
\hline No & Nama Parameter & Jumlah \\
\hline 1 & Arsitektur Jaringan & $5-5-1$ \\
2 & Neuron Input & 5 \\
3 & Neuron Pada Hidden Layer & 5 \\
4 & Neuron Output & 1 \\
5 & Learning Rate & 0.1 \\
6 & Goal & 0.00001 \\
8 & Momentum & 0.95 \\
\hline
\end{tabular}

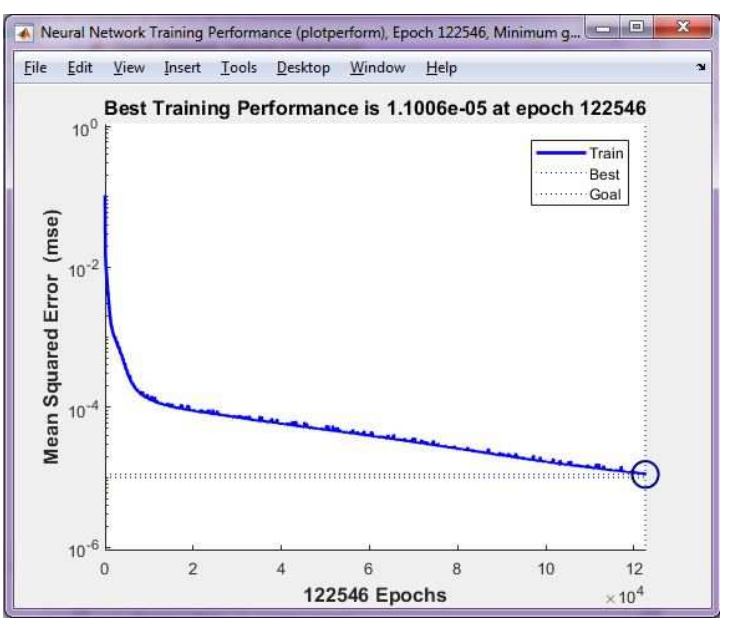

Gambar 7. Grafik Perubahan Nilai MSE terhadap Epoch
Pada Gambar 7 terlihat bahwa hingga epoch 1000 terjadi penurunan yang sanagat tajam dari nilai MSE $10^{-1}$ hingga $10^{-3}$. Penurunan gradient yang signifikan pada proses menuju target menunjukkan bahwa terjadi perbaikan kesalahan, di mana output yang memiliki error besar telah diperkecil dengan melakukan penyesuaian pada masing-masing bobot saat proses Backpropagation . Penurunan saat menuju goal kemudian cenderung landai yang berarti kesalahan yang terjadi sudah semakin kecil.

Pada pelatihan ini, performa terbaik jaringan diperoleh pada nilai MSE $1.1006 \mathrm{e}-05$ di epoch 122546. Berdasarkan hal itu maka dapat dijelaskan bahwa masing-masing bobot jaringan dapat melakukan perbaikan kesalahan dan mengenali input lebih cepat dari epoch yang ditetapkan.

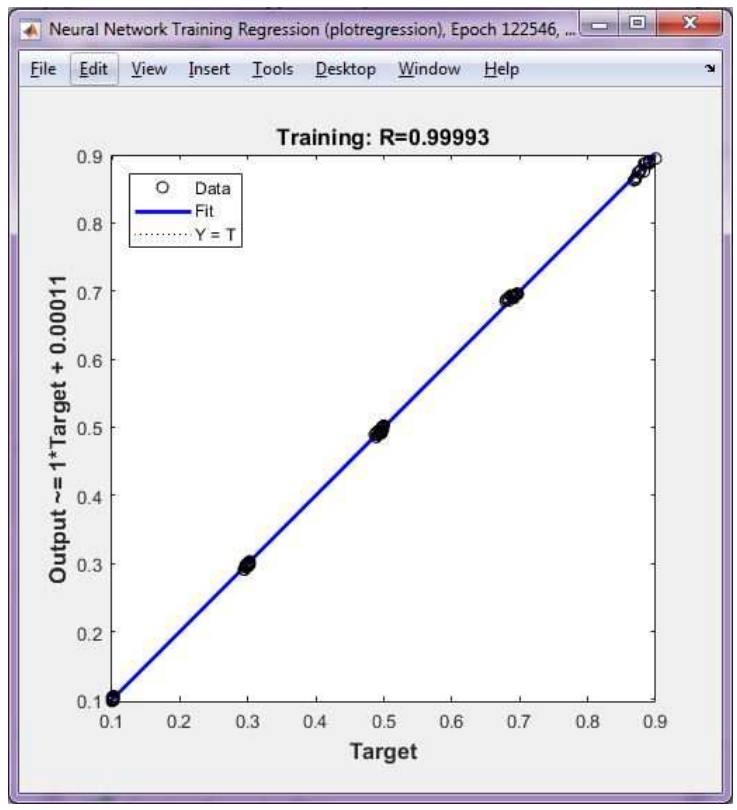

Gambar 8. Grafik Regresi Pelatihan

Akurasi dari pelatihan yang telah dilakukan dapat dilihat dari analisis regresi untuk melihat respon jaringan dan target yang diinginkan. Pada Gambar 8 terlihat hasil regresi dari output $(Y)$ dan target $(X)$ menunjukkan gradient garis hasil regresi linear hampir sama pada satu titik, titik perpotongan dengan sumbu $Y$ pada titik 0 dan koefesien korelasi $(R)$ mendekati 1 (0.99993). Dari ketiga parameter tersebut dapat disimpulkan bahwa output jaringan hampir sama dengan target, berarti 80 data dapat dikenali dengan baik saat pelatihan. Hasil evaluasi analisis regresi menyatakan bahwa jaringan siap digunakan untuk menganalisa dan mengidentifikasi data uji yang diberikan dengan menggunakan parameter-parameter yang diperoleh saat pelatihan. 
Tabel 3. Hasil Pengujian Jaringan Syaraf Tiruan Algoritma Backpropagation Prediksi Frekuensi Resonansi Antena Mikrostrip

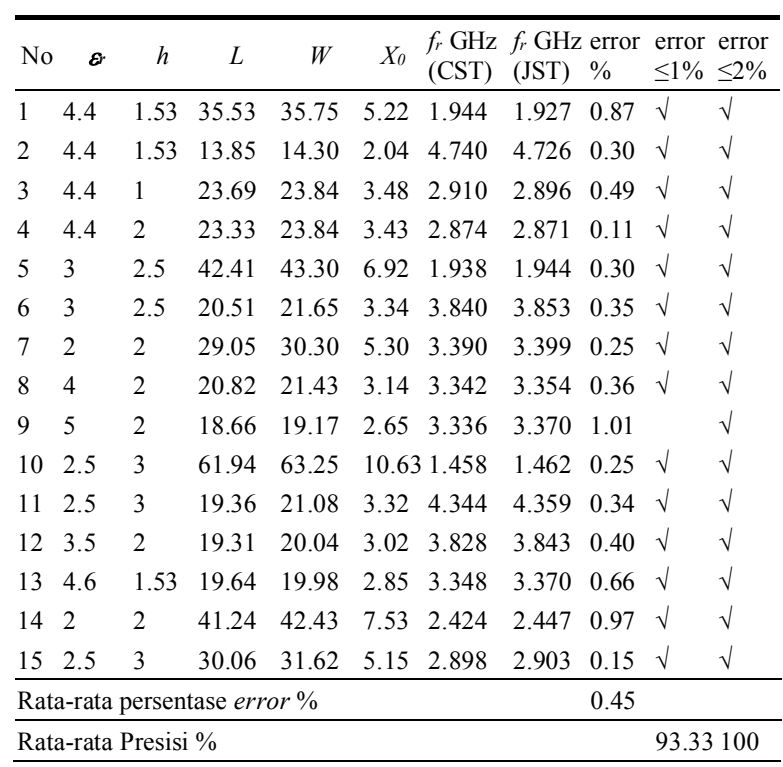

Setelah melalui tahap proses pelatihan, dilakukan proses pengujian dengan menggunakan 15 data uji. Berdasarkan hasil pengujian yang telah dilakukan seperti terlihat pada Tabel 3 didapat ratarata persentase error adalah $0.45 \%$. Rata-rata presisi hasil testing adalah $93.33 \%$ pada nilai error $\leq 1 \%$ dan $100 \%$ pada nilai error $\leq 2 \%$. Hasil pengujian tersebut menunjukkan bahwa pembelajaran Jaringan Syaraf Tiruan backpropagation dengan target goal sebesar 0.00001 dapat digunakan dengan baik untuk memprediksi frekuensi resonansi antena mikrostrip dengan presisi $93.33 \%$ pada nilai error $\leq 1 \%$, dengan rata-rata error sebesar $0.45 \%$. Hasil nilai presisi dapat ditingkatkan dengan cara mengatur nilai target goal mendekati nilai 0 .

\section{KESIMPULAN}

Berdasarkan penelitian dapat dibuat kesimpulan bahwa prediksi frekuensi resonansi antena mikrostrip berdasarkan data input parameter antena dapat dilakukan dengan menggunakan model Jaringan Syaraf Tiruan dengan algoritma backpropagation dengan tingkat presisi $93.33 \%$ dicapai pada nilai error $\leq 1 \%$, dengan rata-rata error $0.45 \%$.

\section{DAFTAR PUSTAKA}

[1] Musa A, Isa A. Prediction of Resonance Frequency of Aperture Coupled Microstrip Antennas by Artificial Neural Network. International Journal of Engineering Sciences \& Research Technology. 5 252-260. 2016.
[2] Shivendra R, Syed S.U., Tanveer S.K. Design of Microstrip Antenna Using Artificial Neural Network. International Journal of Engineering Research and Applications. 3 pp. 461-464. 2013.

[3] Akdagli A, Toktas A, Kayabasi A, Develi I. An Application of Artificial Neural Network To Compute The Resonant Frequency of E-Shaped Compact Microstrip Antennas. Journal of Electrical Engineering. 64 pp. 317-322. 2013.

[4] Sakshi L, Singh V.K. A Novel Approach for Analysis of Bandwidth of Microstrip Patch Antenna Using Neural Network. International Journal of Advanced Research in Computer Science and Software Engineering. 4 pp.637-642. 2014.

[5] Milligan T.A. Modern Antenna Design. John Wiley \& Sons, Inc. pp. 285-355. 2015.

[6] Kapusuz K.Y., Can S, Dagdeviren B. Artificial Neural Network base Bandwidth Estimation of a CPW-Fed Patch Antenna. International Journal of Computer Application. 69 pp. 37-40. 2013.

[7] Pritam S.R., Shamik C. Optimization and improved Bandwidth of Fork shape Microstrip Antenna via Artificial Neural Network. IOSR Journal of Electronics and Communication Engineering (IOSR-JECE), pp. 11 7-12. 2016.

[8] Malvika S, Singhal P.K. Comparative Analysis of Different Artificial Neural Networks for Circular Microstrip Antenna Design. International Research Journal of Engineering and Technology (IRJET). 4. Pp. 2291-2297. 2017.

[9] Rojas R. Neural Networks: a Systematic Introduction. Springer-Verlag, Berlin. 1996.

[10] Siang JJ. Jaringan Syaraf Tiruan dan Pemrogramannya menggunakan Matlab. Andi Offset. 2005.

[11] Vivek S.K., Geetam S.T. Design and Analysis of Microstrip Patch Antennas Using Artificial Neural Network. dlm Sudipta Chattopadhyay. "Trends in Research on Microstrip Antennas." IntechOpen pp. 55-75. 2017.

[12] Yuhandri, Sarifuddin M., Eri P.W., Karmilasari. Pattern Recognition and Classification Using Backpropagation Neural Network Algorithm for Songket Motifs Image Retrieval. International Journal on Advanced Science Engineering Information Technology. 7. Pp. 2343-2349. 2017. 